\title{
Rationally Modified Antimicrobial Peptides from the N-Terminal Domain of Human RNase 3 Show Exceptional Serum Stability
}

\author{
Daniel Sandín, Javier Valle, Belén Chaves-Arquero, Guillem Prats-Ejarque, María Nieves Larrosa, \\ Juan José González-López, María Ángeles Jiménez, Ester Boix,* David Andreu,* and Marc Torrent*
}

Cite This: J. Med. Chem. 2021, 64, 11472-11482

Read Online

ABSTRACT: Multidrug resistance against conventional antibiotics poses an important threat to human health. In this context, antimicrobial peptides (AMPs) have been extensively studied for their antibacterial activity and promising results have been shown so far. However, AMPs tend to be rather vulnerable to protease degradation, which offsets their therapeutic appeal. Here, we demonstrate how replacing functional residues in the antimicrobial region of human RNase 3-also named eosinophil cationic protein-by non-natural amino acids increases stability in human serum. These changes were also shown to reduce the hemolytic effect of the peptides in general terms, whereas the antimicrobial activity was reasonably preserved. Digestion profiles enabled us to design new peptides with superior stability and lower toxicity that could become relevant candidates to reach clinical stages.

\section{INTRODUCTION}

The increasing spread of antibiotic-resistant bacteria is putting our health system at risk. ${ }^{1-3}$ Misuse and abuse of antibiotic prescriptions in humans and the extended use in animal feeding are leading causes of antibiotic resistance. ${ }^{4}$ In this scenario, in addition to awareness campaigns to curb antibiotic overconsumption, new antimicrobial drugs are urgently needed.

Among the newest emergent agents against resistant bacterial infections, antimicrobial peptides (AMPs) are very promising candidates. ${ }^{5,6}$ AMPs are produced by many organisms to kill pathogens and modulate the host response against infections. $^{7-9}$ Their mode of action is based on bacterial membrane destabilization in a fast and unspecific manner, ${ }^{10}$ although intracellular interactions (i.e., targeting protein synthesis or DNA replicating pathways) have also been reported. ${ }^{11}$ The human RNase A protein family includes proteins with a wide functional repertoire, besides its main ribonuclease activity. ${ }^{12-14}$ Antimicrobial, antihelmintic, antitumor, and cytotoxic actions have been extensively studied. $^{15-19}$ Within this family, human RNase 3, also called eosinophil cationic protein (ECP), has a potent antimicrobial activity against both Gram-negative and Gram-positive bacteria, stronger against the former group. ${ }^{20,21}$ Previous studies located the antimicrobial domain of ECP on the $\mathrm{N}$ terminal region, ${ }^{22,23}$ which could be trimmed down by structure-based design without significant loss of antimicrobial activity. $^{24}$

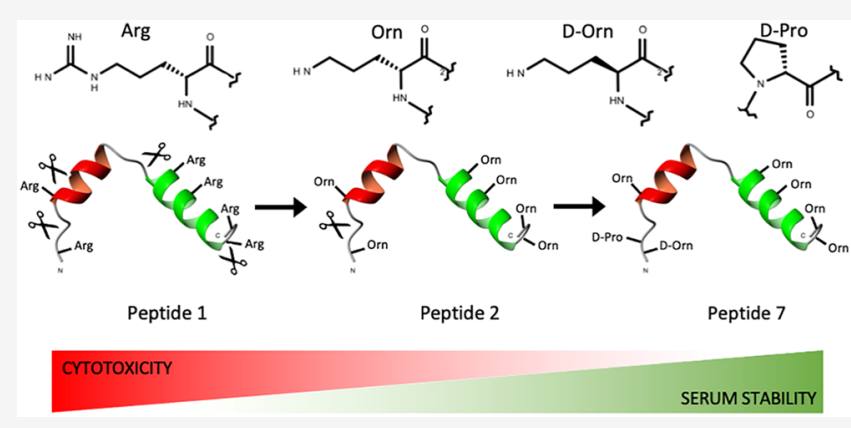

In recent years, several limitations of AMPs, including industrial scale up or high production costs, have been satisfactorily addressed. ${ }^{25}$ Yet, two main drawbacks still preclude their transference to clinics: (i) low stability to serum proteases and (ii) cytotoxicity to host cells. ${ }^{26}$

Here, we designed and tested an optimized fragment from the ECP antimicrobial region (hECP30 peptide) using a rational, structure-guided design with enhanced serum stability and low cytotoxicity effects. ${ }^{27,28}$ First, we analyzed the digestion pattern of hECP30 and identified its most vulnerable points for protease degradation. Following Arg replacement with non-proteinogenic surrogates (Figure 1), we created a highly stable fragment with a half-life above $6 \mathrm{~h}$ in the presence of human serum. These peptide analogs have similar antimicrobial activity against Gram-negative bacterial strains, including clinical isolates, but low toxicity compared to the original peptide. We envision that such modified versions of hECP30 may be suitable candidates for the design of new antimicrobial drugs.

Received: May 1, 2021

Published: August 3, 2021 


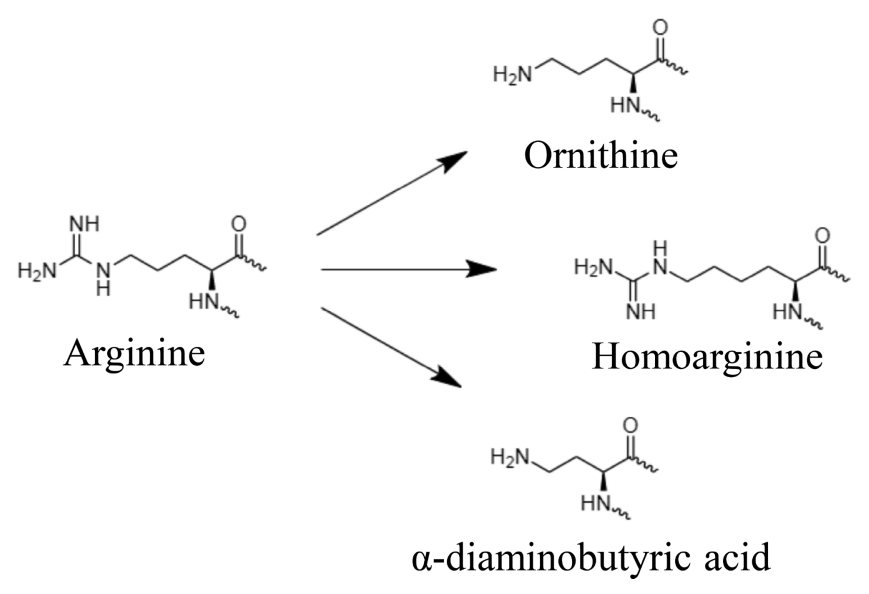

Figure 1. Structure of the amino acids chosen to replace Arg in the ECP-derived peptide.

\section{RESULTS}

Rational Design of ECP Analogs and Stability in Serum. hECP30 (1, Table 1) is a 30-amino acid peptide with strong antimicrobial activity against Gram-negative bacteria, both in planktonic culture and biofilms. ${ }^{29}$ It includes six Arg residues, $20 \%$ of the total in its sequence. Arg and Lys are common targets for trypsin-like serine proteases. ${ }^{30}$ To avoid inactivation by protease cleavage, non-natural amino acid substitution is often used. ${ }^{31}$ In this case, replacement of all Arg residues in 1 by non-proteinogenic, cationic Orn, Dab, and Har improved stability in a moderate $(\sim 2$-fold $)$ but significant way (Table 2).

The incubation profile of $\mathbf{1}$ with human serum shows extensive degradation, even at short times (Figure 2A). Although the three analogs are also rapidly degraded, they generate a second peak that is very stable over time, only further degraded at much longer incubation times (Figure 2 and Figures S1 and S2). These results suggest that Arg replacement protects all susceptible peptide bonds except one.

Most of the digestion subproducts could be identified by MS (Table 3), including the fragment with high stability (over 2 $\mathrm{h}$ ), which was assigned to the original 1 peptide minus the first two N-terminal amino acids, $\operatorname{Arg}^{1}-\mathrm{Pro}^{2}$. To confirm this assignment, Des-OP (5, Table 1), a peptide lacking $\operatorname{Arg}($ Orn)Pro at the $\mathrm{N}$-terminus and with Arg to Orn replacements at the other five positions, was prepared and tested, showing indeed a rather long half-life $(>480 \mathrm{~min})$. Prediction of the protease degradation profile using a bioinformatic tool (https://web. expasy.org/peptide_cutter/) identified proline endopeptidase
Table 2. Peptide Half-Life Time in Incubations with $50 \%$ (v/v) Human Serum

$\begin{array}{cc}\text { peptide } & \text { half-life time }(\mathrm{min}) \\ \mathbf{1} & 12.3 \pm 0.4 \\ 2 & 29.1 \pm 0.5 \\ 3 & 20.6 \pm 3.6 \\ 4 & 16.6 \pm 0.5 \\ 5 & >480 \\ 6 & >480 \\ 7 & >480\end{array}$

as responsible for this fragment. On this basis, we argued that shielding of the $\mathrm{Pro}^{2}-\mathrm{Phe}^{3}$ peptide bond should prevent or minimize protease cleavage. To test this hypothesis, we synthesized two peptides where $\mathrm{Pro}^{2}$ was mutated to D-Pro and Orn was either in the L- or D-configuration (Op (6) and Op (7) analogs, respectively, Table 1). Both peptides displayed a strong improvement in stability, compared to 1 and 2 . The $t_{1 / 2}>480$ min observed for peptides 6 and 7 represents a 30fold stability increase over 1 (Table 2).

Antimicrobial Activity. The antimicrobial activity of all peptides was measured and expressed as the minimal inhibitory concentration (MIC) against several bacterial strains. As ECP and $\mathbf{1}$ are most active against Gram-negative bacteria, MIC was determined against such bacterial species, including Escherichia coli, Acinetobacter baumannii, Pseudomonas sp., Salmonella enterica, Klebsiella pneumoniae, and Shigella flexneri. The results confirmed the high antimicrobial activity of $\mathbf{1}$ against all Gramnegative strains (Table 4). Arg replacement with nonproteinogenic amino acids slightly reduced the activity, especially for 3 (Table 4). Analog 5, which lacks the first two $\mathrm{N}$-terminal residues, showed a marked reduction of activity against all strains, suggesting that these two residues are essential. Analog 7 had similar activity than the original peptide while 6 performed worse against some strains. Altogether, these results suggested that structural differences between 6 and 7 affect antimicrobial activity. All peptides show a minimal bactericidal concentration (MBC) within the same range as the MIC (Table S1). Results obtained by killing curve analysis for analogs 1, 3, 6, and 7 also support these observations (Figure S3). In any event, most peptides display similar or slightly lower antimicrobial activity than LL-37, a well-known reference AMP (Table 4). When peptides were preincubated with human serum and tested against Pseudomonas $s p$., we observed only a slight increase in the MIC values, suggesting that the peptide activity is barely affected by the presence of serum proteins (Table S2).

Table 1. Primary Structures, HPLC Retention Times, and Molecular Mass of hECP30 Synthetic Analogs

\begin{tabular}{|c|c|c|c|c|c|}
\hline \multirow[b]{2}{*}{ entry } & \multirow[b]{2}{*}{ description } & \multirow[b]{2}{*}{ sequence $^{a}$} & \multirow[b]{2}{*}{ HPLC retention time $(\mathrm{min})^{b}$} & \multicolumn{2}{|c|}{ molecular mass $(\mathrm{Da})$} \\
\hline & & & & theory & found \\
\hline 1 & hECP30 & RPFTRAQWFAIQHISPRTIAMRAINNYRWR & 8.9 & 3757.4 & 3757.6 \\
\hline 2 & Orn analog & OPFTOAQWFAIQHISPOTIAMOAINNYOWO & 8.4 & 3505.2 & 3505.2 \\
\hline 3 & Dab analog & XPFTXAQWFAIQHISPXTIAMXAINNYXWX & 8.3 & 3420.9 & 3421.3 \\
\hline 4 & Har analog & ZPFTZAQWFAIQHISPZTIAMZAINNYZWZ & 9.1 & 3841.5 & 3842.2 \\
\hline 5 & $\operatorname{Des}\left[\right.$ Orn $^{1}-$ Pro $\left.^{2}\right]$ analog & --FTOAQWFAIQHISPOTIAMOAINNYOWO & 10.8 & 3293.9 & 3293.8 \\
\hline 6 & {$\left[\right.$ Orn, $\left.{ }^{1} \mathrm{D}-\mathrm{Pro}^{2}\right]$ analog } & OPFTOAQWFAIQHISPOTIAMOAINNYOWO & 10.9 & 3505.2 & 3505.2 \\
\hline 7 & {$\left[\mathrm{D}-\mathrm{Orn},{ }^{1} \mathrm{D}-\mathrm{Pro}^{2}\right]$ analog } & OPFTOAQWFAIQHISPOTIAMOAINNYOWO & 10.8 & 3505.2 & 3505.2 \\
\hline
\end{tabular}

${ }^{a} \mathrm{O}$, ornithine; X, 2,4-diaminobutyric acid; Z, homoarginine; D-amino acid residues in lower case. ${ }^{b}$ All peptides were analyzed by HPLC in a linear gradient of solvent $\mathrm{B}$ (acetonitrile) into solvent $\mathrm{A}\left(\mathrm{H}_{2} \mathrm{O}\right)$ from 0 to $60 \%$ over $15 \mathrm{~min}$. 

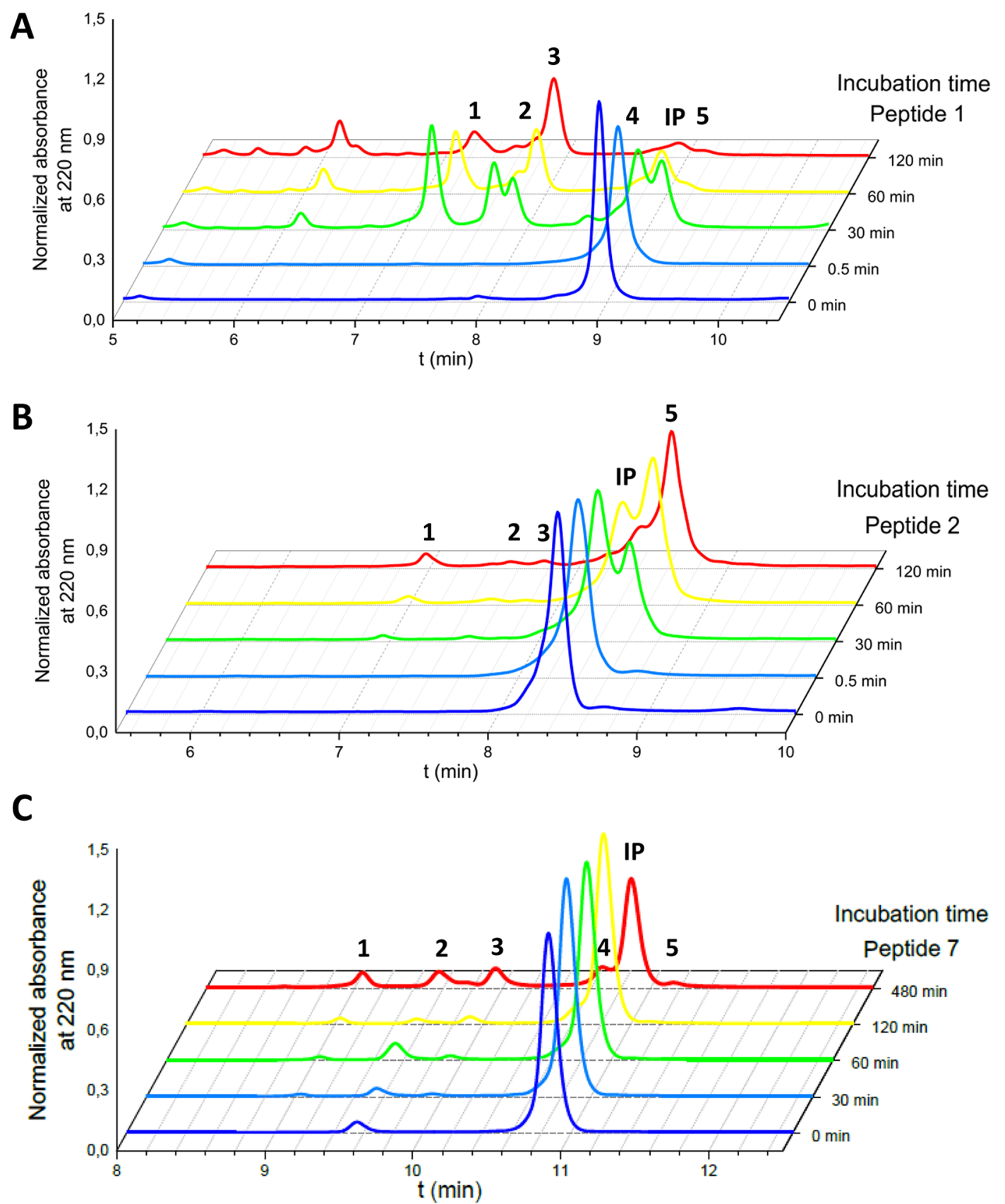

Figure 2. Peptide degradation profiles. $1 \mathrm{mM}$ peptide stocks in water were incubated with human serum (1:1 v/v). Profiles shown are (A) hECP30 reference peptide $1,(B)$ peptide 2 , and (C) peptide 7 . The amount of peptide remaining after incubation at different times was quantified by HPLC analysis. Peak numbers in each panel correspond to fragments listed on Table 3. IP: intact peptide.

Table 3. Sequence of the Original Orn Analog Peptide 2 and Digestion Fragments Generated in Serum Incubations ${ }^{a}$

\begin{tabular}{ll}
\multicolumn{1}{c}{ fragment } & \multicolumn{1}{c}{ sequence } \\
$\mathbf{1}$ & OPFTOAQWFAIQHISPO------------ \\
$\mathbf{2}$ & ---------------- TIAMOAINNYOWO \\
$\mathbf{3}$ & OPFTOAQWFAIQHIS------------- \\
$\mathbf{4}$ & $------Q W F A I Q H I S P O T I A M O A I N N Y---$ \\
$\mathbf{5}$ & -- FTOAQWFAIQHISPOTIAMOAINNYOWO \\
intact peptide & OPFTOAQWFAIQHISPOTIAMOAINNYOWO
\end{tabular}

${ }^{a}$ The fragments are classified in order of elution in HPLC analysis.

In addition to the above reference strains, we also performed MIC assays on several clinical isolates. For some strains, i.e., $P$. aeruginosa and $S$. typhimurium, the concentrations required to inhibit bacterial growth were, on average, higher compared to the original peptide. Such behavior may be related to a higher net charge requirement to disrupt the cell membrane, as Orn is less basic than Arg. ${ }^{32}$ For E. coli and A. baumannii, MIC values for analogs were similar, or even better, than the reference peptide and, in general terms, 7 was substantially more active than 6 (Table 5). It is also worth noting that both hECP30 and its D-amino acid analogs show high activity against $A$. baumannii clinical isolates (Table 5), even at submicromolar concentrations. We also tested whether recurrent incubation of bacteria with peptides could induce resistance. To test for antibiotic resistance, we incubated E. coli cells for 7 rounds of evolution with concentrations below the MIC for the reference 
Table 4. MIC ( $\mu \mathrm{M})$ and Percentage of Hemolysis of hECP30 (1) and Analogs ${ }^{a}$

\begin{tabular}{|c|c|c|c|c|c|c|c|}
\hline peptide & E. coli & A. baumannii & Pseudomonas sp. & S. enterica & S. flexneri & hemolysis $\%$ (250 $\mu \mathrm{M}$ peptide) & MRC-5 cytotoxicity $\left(\mathrm{IC}_{50}, \mu \mathrm{M}\right)$ \\
\hline 1 & 1.56 & 1.56 & 1.56 & 12.5 & 3.13 & $44 \pm 4$ & $23 \pm 4$ \\
\hline 2 & 6.25 & 6.25 & 6.25 & 25 & 12.5 & $10 \pm 2$ & $113 \pm 8$ \\
\hline 3 & 6.25 & 50 & 3.13 & 50 & 6.25 & $14 \pm 6$ & $182 \pm 9$ \\
\hline 4 & 6.25 & 12.5 & 3.13 & 25 & 3.13 & $43 \pm 1$ & $7.6 \pm 0.7$ \\
\hline 5 & 25 & $>100$ & 25 & $>100$ & 50 & $11 \pm 4$ & $>300$ \\
\hline 6 & 3.13 & 12.5 & 1.56 & 50 & 50 & $1.1 \pm 0.9$ & $230 \pm 40$ \\
\hline 7 & 3.13 & 6.25 & 1.56 & 25 & 6.25 & $3.6 \pm 0.7$ & $170 \pm 20$ \\
\hline LL-37 & 1.56 & 6.25 & 1.56 & 12.5 & 12.5 & $58 \pm 7$ & $64 \pm 2$ \\
\hline
\end{tabular}

Table 5. MIC Values $(\mu M)$ of hECP30 (1) and Analogs in Clinical Bacterial Strains

\begin{tabular}{lccc}
\multicolumn{1}{c}{ strain } & peptide 1 & peptide 6 & peptide 7 \\
E. coli 116878 & 6.25 & 25 & 6.25 \\
E. coli cf073 & 3.13 & 6.25 & 3.13 \\
P. aeruginosa 827651 & 25 & 25 & 100 \\
P. aeruginosa 827632 & 12.5 & $>100$ & 25 \\
S. typhimurium 324 & 6.25 & 25 & 25 \\
S. typhimurium 365 & 6.25 & 25 & 25 \\
A. baumannii 3862 & 0.78 & 1.56 & 0.78 \\
A. baumannii 3878 & 1.56 & 0.78 & 0.78 \\
A. baumannii 3879 & 1.56 & 3.13 & 1.56 \\
A. baumannii 3880 & 1.56 & 12.5 & 6.25 \\
\hline
\end{tabular}

peptide 1 as well as analogs 6,7 , and LL-37 $(1 \mu \mathrm{M})$ and ciprofloxacin $(1 \mu \mathrm{M})$ as a positive control. We did not detect a significant increase in MIC for any of the compounds tested (Figure S4), whereas ciprofloxacin-treated cells increased their MIC from 1.5 to $5.0 \mu \mathrm{M}$ after four cycles of incubation.

Mechanism of Action. The mechanism of action was elucidated by membrane depolarization and scanning electron microscopy (SEM). To study membrane depolarization, we used bacterial cells stained with the lipophilic dye $\operatorname{DiSC}_{3}(5)$. In this assay, when membranes are compromised after peptide incubation, an increase in fluorescence is detected. Peptides 1, $\mathbf{2 , 6}$, and 7 displayed similar depolarization capacity although the kinetics was slightly slower for analog 6 (Figure S5). LL-37 was used as a positive control and showed a similar dye release, confirming the ability of all analogs to disrupt the bacterial cell membrane (Figure S5). Membrane damage was also studied by SEM in live bacteria. Peptide incubation showed in all cases a marked membrane damage, with blebs confirming that the structural integrity was compromised (Figure 3 ). The presence of blebs distributed all along the bacterial surface, the disruption of the cell morphology, and the presence of debris outside the cell suggest a carpet-like mechanism, as observed before for the ECP N-terminal domain, ${ }^{22}$ reinforcing the idea that the mechanisms of action of these analogs are similar.

Toxicity Analysis. The antimicrobial activity must not be analyzed on its own but assessed alongside peptide toxicity. It is well known that unspecific and potent antimicrobial activity is often accompanied by high cytotoxicity against host cells. $^{33,34}$ In our case, we tested cytotoxicity caused by the peptide by measuring lysis of horse red blood cells as monitored by hemoglobin release at $540 \mathrm{~nm} .^{35}$ The assay showed a high activity for reference peptide 1 , with $\sim 50 \%$ lysis at $250 \mu \mathrm{M}$, similar to LL-37 (Table 4). In contrast, 2 and 3 showed an important reduction in toxicity, with only $10 \%$ hemolysis at the same concentration (Table 4). For its part,
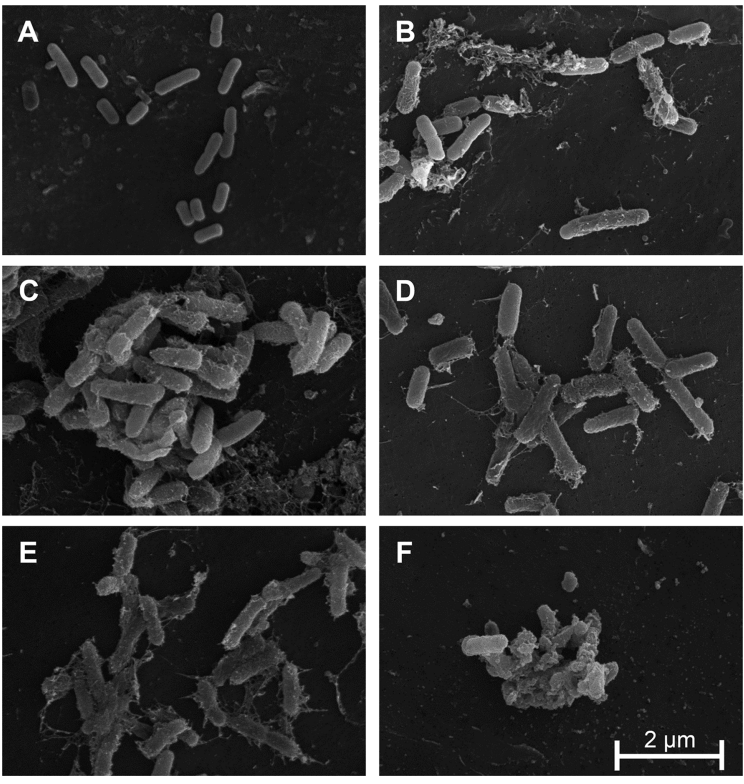

Figure 3. SEM images of $E$. coli in the mid-exponential phase (A) before treatment or after treatment with $10 \mu \mathrm{M}$ of analogs (B) $1,(\mathrm{C})$ 2, (D) 6, (E) 7, or (F) LL-37.

the Har analog 4 showed lysis levels similar to 1 (42.86 \pm $1.29 \%)$, suggesting that cytotoxicity is strongly related to cationic charge. Most interestingly, analogs 6 and 7 showed a massive reduction in cytotoxicity $(1.12 \pm 0.93$ and $3.59 \pm$ $0.69 \%$, respectively), thus broadening the therapeutic window relative to the reference peptide.

The above results were compared to cytotoxicity assays in MRC-5 cells using the MTT assay. Results confirmed the high toxicity of peptides 1 and 4, with $\mathrm{IC}_{50}$ values of 23 and $7.6 \mu \mathrm{M}$, respectively. In line with the hemolytic results, the toxicity of analogs 2 and 3 was markedly reduced, with $\mathrm{IC}_{50}$ values increased up to $180 \mu \mathrm{M}$ (Table 4). No toxicity was detected for analog 5, even at the highest concentration tested, concurring with its low antimicrobial activity. Finally, analogs 6 and 7 exhibited even lower toxicity than 5 , with $\mathrm{IC}_{50}$ values up to $230 \mu \mathrm{M}$. Such low toxicity, combined with a longer halflife, motivated us to further study these peptides from a structural point of view.

Peptide Structure. A preliminary evaluation of the structure of peptides 1, 2, 6, and 7 was provided by circular dichroism. Far UV spectra of peptides in aqueous solution or in the presence of SDS micelles $(1 \mathrm{mM})$ were recorded. Spectra for all four peptides indicated a random conformation in aqueous solutions (Figure S6 and Table S3). Upon addition of SDS, the peptides adopted a more defined structure, mainly 

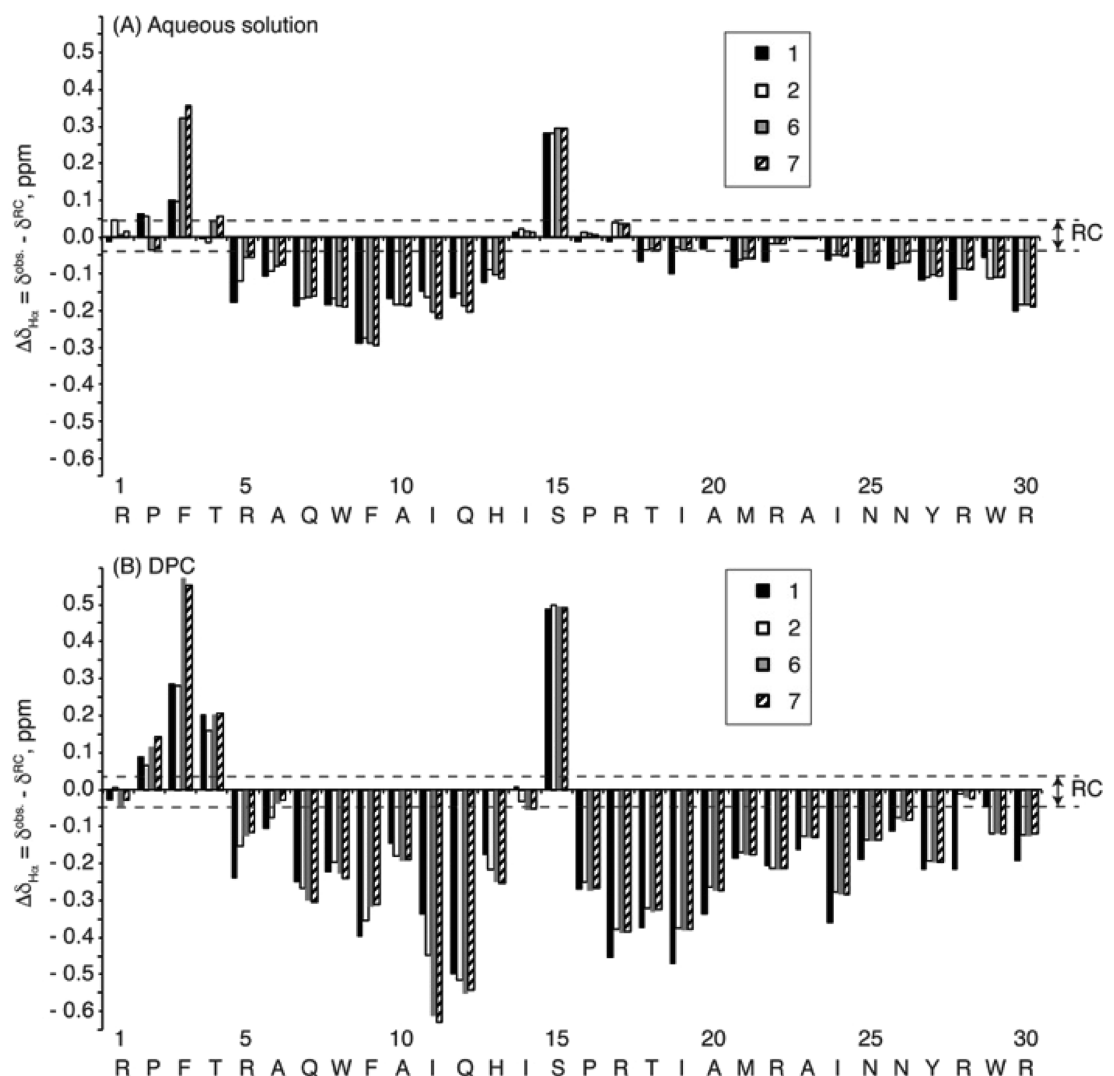

Figure 4. Bar plots of the $\Delta \delta_{\mathrm{H} \alpha}$ values $\left(\Delta \delta_{\mathrm{H} \alpha}=\delta_{\mathrm{H} \alpha}{ }^{\text {observed }}-\delta_{\mathrm{H} \alpha}{ }^{\mathrm{RC}}\right.$, ppm) as a function of sequence for peptides 1, 2, 6, and 7 in (A) aqueous solution and (B) DPC micelles at pH 4.4 and $25^{\circ} \mathrm{C}$. Notice that the sequence of peptide $\mathbf{1}$ is shown and that Arg residues are Orn in peptides 2, 6, and 7 .

$\alpha$-helical, in percentages ranging from 45 to $57 \%$, consistent with previous results reported by our group for the ECP Nterminal domain (Table S3). ${ }^{22}$

Peptides 1, 2, 6, and 7 were studied in aqueous solution and dodecylphosphocholine (DPC) micelles by NMR. All four peptides exhibited a helical segment spanning residues 5-13 and a slight helical tendency at residues $16-27$ in aqueous solution, based on the analysis of the conformational shifts $\left(\Delta \delta_{\mathrm{H} \alpha}\right.$ and $\Delta \delta_{\mathrm{C} \alpha} ;$ Figure 4, Table S4, and Figure S7). According to the magnitudes of the conformational shifts, both helices become more populated in the presence of DPC, in tune with the notion that micelles tend to stabilize amphipathic helices. $^{36,37}$ On the whole, the peptides do not show any significant differences in secondary structure, i.e., helices span the same residues and there are no great differences in their populations (Table S4). More specifically, in aqueous solution, all four peptides show a well-defined $\mathrm{N}$-terminal helix spanning residues 5-13, the only ones with non-sequential NOEs, and a mainly disordered C-terminal tail (Figure 5A, Figures S8 and S9, and Table S5). In contrast, in DPC micelles, the helix populations are higher and are better defined for the entire peptide length (Figures S8 and S9 and Table S5), with two helical regions spanning residues 5-13 and 16-27 (Figure $5 B)$. A closer inspection reveals interesting differences among the four peptides, however, in the relative orientation of the helices (Figure 5C,D), and at the $\mathrm{N}$-termini, where the $\mathrm{D}$ residues in $\mathbf{6}$ and 7 also give rise to some variations. A detailed examination of side-chain packing at the $\mathrm{N}$-terminal region (residues 1-15, including helix 5-13) was performed on the DPC structures, essentially identical to those in aqueous solution but better defined (Figure S7 and Table S5). In the four peptides, the helix exhibits a hydrophobic patch formed by residues F3, W8, I11, and I14 (Figure 6). The arrangement of these side chains seems to be slightly different in 1 compared to the other analogs. The hydrophobic patch extends to D-Pro2 in the case of 6 and 7 .

\section{DISCUSSION AND CONCLUSIONS}

The replacement of original residues in peptides by nonproteinogenic or D-amino acids has been extensively studied over recent years to enhance AMP viability for clinical use. ${ }^{38}$ In AMPs, Arg and Lys are key cationic residues often involved in interactions with negatively charged bacterial membranes. However, these two residues are also a frequent target of serum proteases, with ensuing peptide inactivation. In hECP30, Arg represents $20 \%$ of the amino acid content; hence, we decided to investigate whether its replacement by non-coded surrogate residues could improve peptide stability and therapeutic potential.

We first observed that substituting Arg by Orn, Dab, or Har could moderately stabilize hECP30 against proteolytic cleavage in human serum (Table 2). This increase in half-life, up to 3fold for analog 2, may be explained by impaired recognition of Orn at the active site of proteases. Analyzing the degradation profile by HPLC-MS, we found an extremely stable cleavage byproduct in the modified analogs. This fragment had lost only the two residues (Orn and Pro) at the N-terminus; thus, we hypothesized that peptide 5 might be an interesting analog, largely impervious to proteolytic cleavage. Unfortunately, the improved stability was accompanied by low activity against 


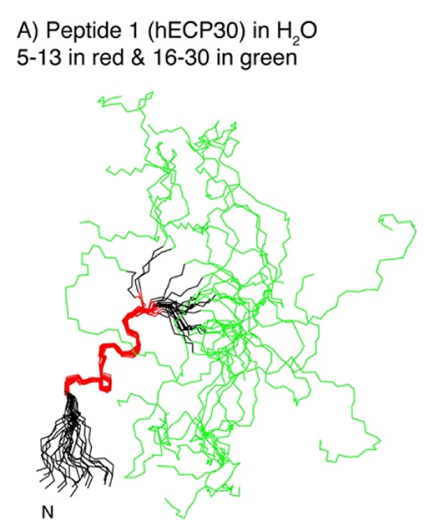

C) Structures in DPC overlaid onto residues 5-13

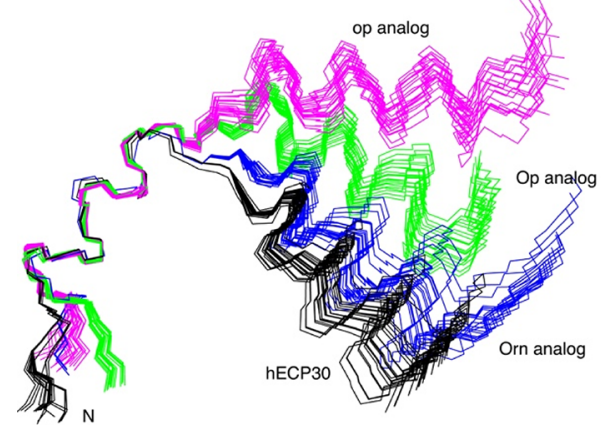

B) Peptide 1 (hECP30) in DPC

$5-13$ in red \& $16-27$ in green

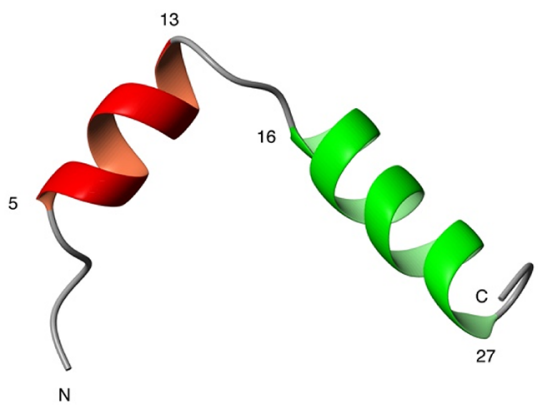

D) Structures in DPC overlaid onto residues 16-27

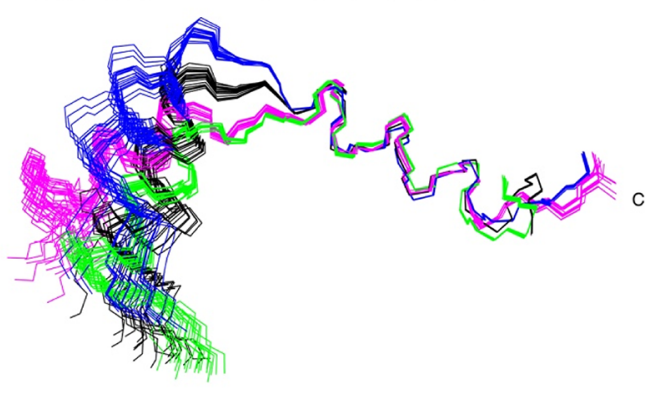

Figure 5. Peptide NMR calculated structures. (A) Ensemble of the 20 lowest target function structures of peptide $\mathbf{1}$ in aqueous solution overlaid onto residues 5-13. Residues 5-13 in red and 16-30 in green. (B) Ribbon representation of the lowest target function structure for peptide 1 in DPC micelles. (C, D) Ensembles of the 20 lowest target function NMR calculated structures for peptide 1 (black), 2 (blue), 6 (green), and 7 (magenta) analogs in DPC micelles overlaid onto residues 5-13 (panel C) and onto residue 16-27 (panel D).

bacterial strains, strongly suggesting that these first two residues are essential for antimicrobial action and cannot be omitted. Discarding therefore $\mathbf{5}$ as a candidate and analyzing the in silico peptide degradation profile by known serum proteases, we found that the $\mathrm{Pro}^{2}-\mathrm{Phe}^{3}$ bond was cleavable by a proline endopeptidase and hence decided to test two new analogs with either $\mathrm{Pro}^{2}$ or both $\mathrm{Orn}^{1}$ and $\mathrm{Pro}^{2}$ replaced by the corresponding D-enantiomers. As hypothesized, the new analogs exhibited remarkable serum stability, improving over 30 -fold the half-life ( $>6 \mathrm{~h}$ vs $12 \mathrm{~min}$ for reference peptide 1) and thus confirming that shielding the $\mathrm{Pro}^{2}-\mathrm{Phe}^{3}$ peptide bond from cleavage was crucial for stability. This is a remarkable improvement when compared to similar studies. ${ }^{39}$

Having improved stability, we next tested the impact of these changes on antimicrobial activity. We had detected a slight decrease in both analogs 2 and 3, whereas the replacement of Arg by Har was neutral in terms of antimicrobial activity. These findings are readily explainable in structural terms: Har is very similar to Arg, both having a long side chain ending in a strongly cationic guanidine group, whereas Orn and Dab have shorter side chains ending in less basic amino functions (Figure 1). Importantly, shielding the $\mathrm{Pro}^{2}-\mathrm{Phe}^{3}$ bond by D-amino acid replacement in Orn analogs 6 and 7 improved both the half-life and the antimicrobial activity. Thus, MIC values for 7 were similar to the original peptide in almost all bacteria, both reference and clinical strains (Tables 4 and 5). These results suggest that bacteria may also use their own proteases to cleave peptides as a protective strategy, as observed before for other AMPs. ${ }^{40}$ Membrane depolarization assays and SEM images confirmed that the mechanism of action of the analogs is similar to the original ECP N-terminal domain, suggesting that the peptides would display a carpet-like mechanism. ${ }^{22}$ Also, no antimicrobial resistance was observed after cyclic incubations of bacteria with the peptides, suggesting that bacteria are less prone to developing resistance against these peptides compared to conventional antibiotics.

To measure the potential toxicity of the peptides, we performed assays to define in vitro therapeutic windows. Reference peptide 1 caused $\sim 50 \%$ hemolysis at $250 \mu \mathrm{M}$ concentration (Table 4). Although this value may seem high, one must be reminded that it is about 100 -fold the MIC in E. coli. Indeed, at lower concentrations, e.g., 10-fold the MIC, hemolytic activity is below $10 \%$. On the other hand, while analogs 2 and 3 show a marked decrease in hemolytic activity, for 4, the antimicrobial and hemolytic activities almost coincide, again suggesting that the chemical nature of the cationic residues is highly relevant for the mechanism of action. Thus, the strong cationic nature of Arg and Har increases antimicrobial activity of both peptides, by strongly binding the negatively charged bacterial membrane, whereas the long side chains also enhance, after charge neutralization, the hydrophobic nature of the residues, probably increasing hemolytic activity. Consistently with this hypothesis, Dab and Orn cause a marked reduction in hemolysis $(<5 \%$ at $250 \mu \mathrm{M}$ in both cases) and a slight decrease in activity which, upon $\mathrm{N}$-terminal protease shielding (analogs 6 and 7), rescues the antimicrobial potency of the original peptide.

To investigate whether the amino acid substitutions translated into peptide structure changes, we performed 

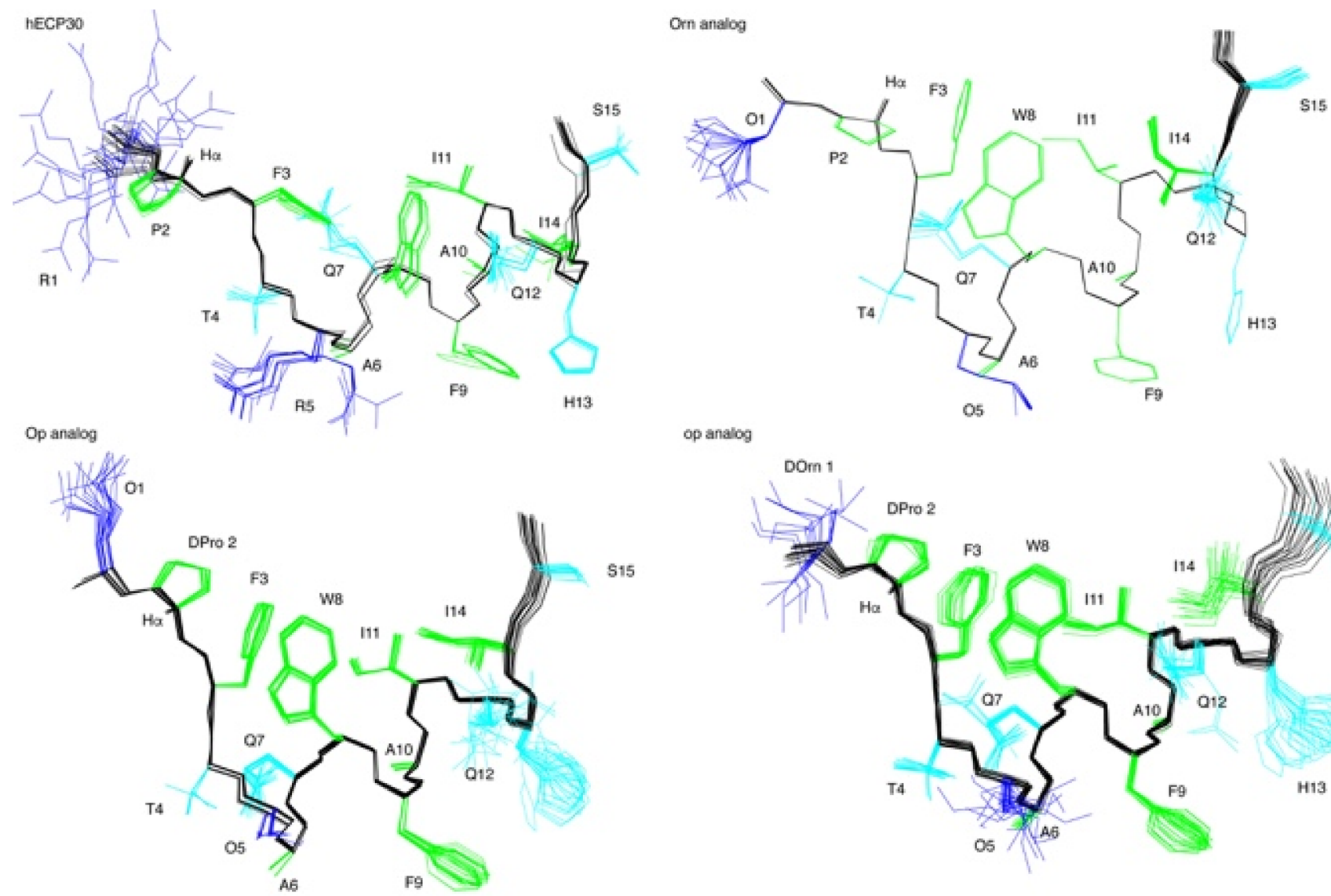

op analog

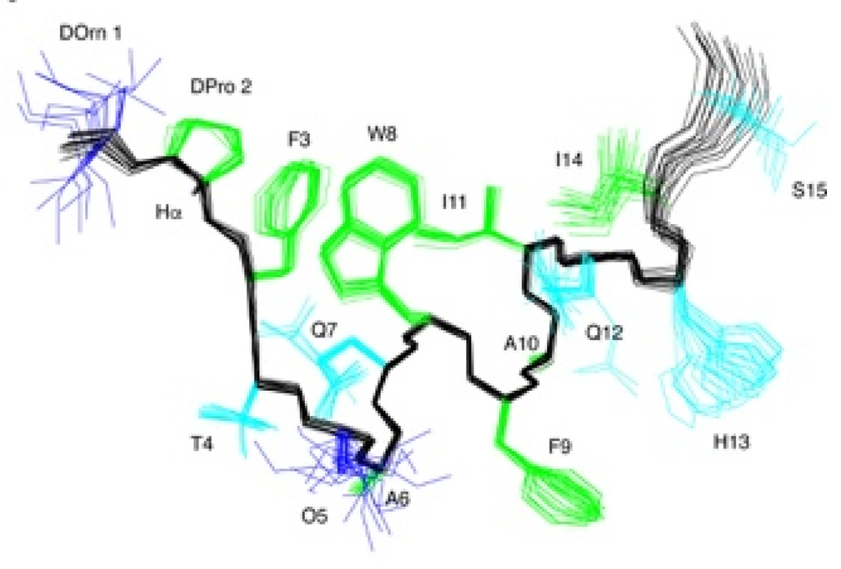

Figure 6. N-terminal regions (residues 1-15) of the NMR calculated structures for peptides 1, 2, 6, and 7 in DPC micelles. Backbone atoms are displayed in black, Arg and Orn side chains in blue, polar side chains in cyan, and aliphatic and aromatic side chains in green. The $\mathrm{H}_{\alpha}$ proton of Pro and D-Pro residues is shown.

NMR analysis on the most promising candidates $(1,2,6$, and 7 ) and found that the overall structure is conserved, with two main $\alpha$-helices spanning residues 5-13 and 16-27 (Figures 3 and 4 ). The two helices are weakly formed in aqueous solution (30-40 and $10-15 \%$ for helices 5-13 and 16-27, respectively) but clearly defined in the presence of DPC micelles $(70-80 \%)$. This is consistent with most AMPs and previous studies on the antimicrobial domain of $\mathrm{ECP}^{24,41}$ in contact with the negatively charged bacterial membrane. Even so, a slight conformational change in the second helix is observed in 2, 6, and 7 relative to $\mathbf{1}$ : the angle between the two helices increases upon replacing Arg by Orn, with peptides 2, 6, and 7 adopting a more extended conformation that may help explain the slightly lower activity of Orn analogs compared to the original peptide.

In light of the present results, we conclude that peptide 7 is a promising AMP lead. Its high antimicrobial activity and low cytotoxicity portray it as an excellent candidate to fight infections caused by Gram-negative bacteria. Moreover, its remarkable in vitro serum stability suggests that it would survive in the organism for a prolonged time.

\section{EXPERIMENTAL SECTION}

Materials. Purified horse red blood cells were acquired from Thermo Fisher Scientific (Hampshire, England). Human serum was purchased from Sigma (St Louis, USA). E. coli was obtained from the Coli Genetic Stock Center (BW25113). S. flexneri (ATCC 29903), A. baumannii (ATCC 15308), Pseudomonas sp. (ATCC 15915), and S. enterica (ATCC 14028) were obtained from the CECT (Valencia,
Spain). Clinical strains were supplied by the Vall d'Hebron Hospital (Barcelona, Spain). MRC5 fibroblasts were obtained from the Cytometry and Cell Culture Facility (SCAC, UAB) and originally purchased from ATCC.

Peptide Synthesis. Peptides were assembled in the C-terminal carboxamide form at a $0.1 \mathrm{mmol}$ scale on a H-Rink AmideChemMatrix resin of $0.50 \mathrm{mmol} / \mathrm{g}$ substitution (PCAS BioMatrix, Quebec, Canada) in a Prelude instrument (Gyros Protein Technologies, Tucson, AZ) using Fmoc solid-phase peptide synthesis (SPPS) protocols. After chain assembly, peptides were fully deprotected and cleaved from the resin with TFA/ $\mathrm{H}_{2} \mathrm{O} /$ triisopropylsilane $(95: 2.5: 2.5 \mathrm{v} / \mathrm{v})$ for $90 \mathrm{~min}$ at $\mathrm{RT}$ with gentle agitation. Peptides were precipitated from the TFA solution by addition of chilled diethyl ether followed by three centrifugations at $4800 \mathrm{rpm}, 5$ min, $4{ }^{\circ} \mathrm{C}$, taken up in water and lyophilized. Crude peptides were checked by analytical RP-HPLC and LC-MS and purified by preparative RP-HPLC. Analytical RP-HPLC was performed on an LC-20 AD instrument (Shimadzu, Kyoto, Japan) fitted with a Luna C18 column $(4.6 \mathrm{~mm} \times 50 \mathrm{~mm}, 3 \mu \mathrm{m}$; Phenomenex $)$ using linear gradients of solvent $\mathrm{B}(0.036 \% \mathrm{TFA}$ in $\mathrm{ACN})$ into A $(0.045 \% \mathrm{TFA}$ in $\mathrm{H}_{2} \mathrm{O}$ ) over $15 \mathrm{~min}$, at $1 \mathrm{~mL} / \mathrm{min}$ flow rate and with UV detection at $220 \mathrm{~nm}$. Preparative RP-HPLC was performed on an LC-8 instrument (Shimadzu) fitted with a Luna C18 column $(21.2 \mathrm{~mm} \times 250 \mathrm{~mm}, 10$ $\mu \mathrm{m}$; Phenomenex), using linear gradients of solvent B (0.1\% TFA in $\mathrm{ACN})$ into $\mathrm{A}\left(0.1 \%\right.$ TFA in $\left.\mathrm{H}_{2} \mathrm{O}\right)$ over $30 \mathrm{~min}$, with a flow rate of 25 $\mathrm{mL} / \mathrm{min}$. MS analysis was performed on an LC-MS 2010EV instrument (Shimadzu) fitted with an Aeris Widepore XB-C18 column $(150 \times 4.6 \mathrm{~mm}, 3.6 \mu \mathrm{m}$, Phenomenex $)$, eluting with linear gradients of B ( $0.08 \%$ formic acid (FA) in ACN) into A (0.1\% FA in $\mathrm{H}_{2} \mathrm{O}$ ) over $15 \mathrm{~min}$ at a $1 \mathrm{~mL} / \mathrm{min}$ flow rate. Fractions of $>95 \% \mathrm{HPLC}$ purity and with the expected mass by LC-MS were pooled and lyophilized. Peptide purity was assessed by the area of the purified 
peptide peak relative to the total peak areas in the chromatogram. Peptide stock solutions were prepared in sterile deionized water and stored at $-20{ }^{\circ} \mathrm{C}$.

Peptide Stability. To determine stability, $1 \mathrm{mM}$ peptide stocks were incubated with human serum in a 1:1 ratio. At various incubation times, aliquots were removed, and digestion was stopped by ACN precipitation. After discarding serum proteins by centrifugation, original peptides and proteolysis fragments in the supernatant were analyzed by LC-MS. Solvents and methods are as above. Results are the average of three independent studies.

Minimum Inhibitory Concentration (MIC) and Minimum Bactericidal Concentration (MBC). The antibiotic activity was defined by the minimum peptide concentration where the microorganism is unable to grow. The assay was done in polypropylene 96well plates (Greiner, Frickenhausen, Germany) to avoid peptide binding to plate wells. Peptides were dissolved in water containing $0.4 \% \mathrm{w} / \mathrm{v}$ bovine serum albumin (BSA) and $0.02 \% \mathrm{v} / \mathrm{v}$ glacial acetic acid to prevent self-aggregation, following the reference protocol by Wiegand et al., ${ }^{42}$ based on the classical microtiter broth dilution recommended by the National Committee of Laboratory Safety and Standards (NCLSS). Initial bacteria inoculum was adjusted to $5 \times 10^{5}$ $\mathrm{CFU} / \mathrm{mL}$ in Mueller-Hinton ( $\mathrm{MH})$ medium. Incubations were kept at $37{ }^{\circ} \mathrm{C}$ for $24 \mathrm{~h}$. Results are the average of three independent studies. MIC assays in the presence of serum were performed by incubating the peptide with human serum at a 1:1 ratio. Then, $10^{6}$ $\mathrm{cfu} / \mathrm{mL}$ of Pseudomonas $s p$. were incubated with serial dilutions of the peptides for $4 \mathrm{~h}$. To determine the MBC, $50 \mu \mathrm{L}$ from all wells were seeded into Petri plates and incubated for $24 \mathrm{~h}$. The MBC concentration was attributed to the lowest concentration without detectable bacterial growth for each peptide.

Antimicrobial Resistance. To test whether recurrent incubation of bacteria with peptides could induce resistance, E. coli $\left(10^{7} \mathrm{cfu} / \mathrm{mL}\right)$ were incubated with peptides $(1 \mu \mathrm{M})$ or ciprofloxacin $(1 \mu \mathrm{g} / \mathrm{mL})$ for $1 \mathrm{~h}$. After incubation, cells were centrifuged, washed, and grown overnight in Mueller-Hinton medium. The cycle of incubation and growth was repeated in a cyclic manner for 7 days, and each day, cultures were tested for MIC to detect resistance.

Killing Curve Assay. Killing curves were followed using the live/ dead bacterial viability kit (Invitrogen, Oregon, USA). Briefly, fresh bacteria cultures (E. coli, A. baumannii, and Pseudomonas sp.) were brought to a concentration of approximately $4 \times 10^{8} \mathrm{cfu} / \mathrm{mL}$ for the assay. In a polypropylene 96-well plate (Greiner, Frickenhausen, Germany), $100 \mu \mathrm{L}$ of a 3:2 mixture of bacteria and live/dead reagent in phosphate-buffered saline (PBS), incubated previously for $15 \mathrm{~min}$, was added to each well containing $50 \mu \mathrm{L}$ of $1: 2$ serially diluted peptide in PBS (concentration range from $100 \mu \mathrm{M}$ to $0.2 \mu \mathrm{M}$ ). The fluorescence emission was continuously recorded for $12 \mathrm{~h}$ with a Tecan Infinite F Nano+ microplate reader (Tecan, Germany) using an excitation wavelength of $485 \mathrm{~nm}$. Emission wavelength for SYTO9 was set to $530 \mathrm{~nm}$ (green, living cells) and $630 \mathrm{~nm}$ for propidium iodide (red, dead cells). Results are the average of three independent studies.

Hemolytic Activity. The peptide toxicity was determined detecting the disruption of horse red blood cells, following a previous assay report. ${ }^{35} 10$-fold diluted cells in PBS were centrifuged three times at $800 \mathrm{~g}$ to eliminate the hemoglobin from disrupted cells. After the last resuspension, erythrocytes were incubated with the peptides for $4 \mathrm{~h}$ at $37^{\circ} \mathrm{C}$. The detection was done measuring the supernatant absorbance in a VICTOR3 multilabel plate reader (Perkin Elmer, Waltham, Massachusetts) at $540 \mathrm{~nm}$ in a microplate reader. Percentage of hemolysis was calculated through a pattern done with dilutions of total cell lysis done with a $1 \%$ Triton X-100 buffer. Results are the average of three independent studies.

Bacterial Membrane Depolarization. Membrane depolarization on E. coli was performed by the quenching and later release of $\mathrm{DiSC}_{3}(5)$ (Fisher, Hampshire, England) as described in Zhang et al., with some modifications. ${ }^{43}$ E. coli fresh cultures were brought to exponential growth (0.2-0.4 OD), washed twice with $5 \mathrm{mM}$ HEPES, $20 \mathrm{mM}$ glucose, and $100 \mathrm{mM} \mathrm{KCl}, \mathrm{pH} 7.2$, and finally resuspended with the same buffer up to an OD of 0.05 . Samples were mixed with the dye to a final concentration of $0.4 \mu \mathrm{M}$ and incubated in darkness from 20 to $30 \mathrm{~min}$ to obtain a stable baseline. The peptides were added to the mixture and $\mathrm{DiSC}_{3}(5)$ release was measured in a Varian Cary Eclipse fluorescence spectrometer (Agilent, Santa Clara, California) with excitation and emission at 625 and $666 \mathrm{~nm}$ and 5 $\mathrm{nm}$ and $10 \mathrm{~nm}$ excitation and emission slit, respectively.

Scanning Electron Microscopy (SEM). E. coli cell cultures were grown in $\mathrm{LB}$ at $37^{\circ} \mathrm{C}$ to the mid-exponential phase $\left(\mathrm{OD}_{600}=0.4\right) .1$ $\mathrm{mL}$ of cell culture was incubated for $2 \mathrm{~h}$ with $10 \mu \mathrm{M}$ peptides at room temperature. Samples were then prepared for analysis, as described previously. ${ }^{44}$ Briefly, the cell suspensions were filtered through $0.1 \mu \mathrm{m}$ Nucleopore filters to retain the bacteria and then fixed with $2.5 \%$ glutaraldehyde in $100 \mathrm{~mm} \mathrm{Na-cacodylate} \mathrm{buffer}(\mathrm{pH} \mathrm{7.4)}$ for $2 \mathrm{~h}$ at 4 ${ }^{\circ} \mathrm{C}$. Attached cells were post-fixed by immersing the filters in $1 \%$ osmium tetroxide in $\mathrm{Na}$-cacodylate buffer for $30 \mathrm{~min}$, rinsed in the same buffer, and dehydrated in ethanol in ascending percentage concentrations $[31,70,90(\times 2)$, and $100(\times 2)]$ for 15 min each. The filters were mounted on aluminum stubs and coated with goldpalladium in a sputter coater (K550; Emitech, East Grinsted, UK). The filters were viewed at $15 \mathrm{kV}$ accelerating voltage in a EVO MA 10 scanning electron microscope (Zeiss, Oberkochen, Germany).

Cytotoxicity in Mammalian Cells. MRC- 5 cells were grown in Eagle's minimum essential medium $(\operatorname{MEM} \alpha)$, supplemented with $10 \%$ fetal bovine serum (FBS). 96-well plates were seeded with $3 \times$ $10^{4}$ cells/well and cultured overnight in order to get cells adhered into the plate and then incubated with two-fold peptide serial dilutions. After $4 \mathrm{~h}$ of incubation, the medium containing the peptides was replaced by MEM $\alpha$ supplemented with FBS and 3-(4,5-dimethylthiazol-2-yl)-2,5-diphenyltetrazolium bromide (MTT) at $0.4 \mathrm{mg} / \mathrm{mL}$ and incubated for $150 \mathrm{~min}$. Detection of formazan crystals in the living cells was done by cell disruption by addition of $200 \mu \mathrm{L}$ of dimethyl sulfoxide (DMSO) followed by absorbance measuring at $600 \mathrm{~nm}$ in a Tecan Infinite F Nano+ microplate reader (Tecan, Germany). Results are the average of three independent studies.

Circular Dichroism. The CD spectrum of peptides 1, 2, 6, and 7 was measured in $5 \mathrm{mM}$ sodium phosphate $\mathrm{pH} 7$ or $5 \mathrm{mM}$ sodium phosphate buffer $\mathrm{pH} 7$ with $1 \mathrm{mM}$ SDS to simulate a membrane environment. Peptide final concentration was $10 \mu \mathrm{M}$. Samples were analyzed in a Jasco J-815 CD spectropolarimeter (Jasco, Easton, Maryland) in $0.2 \mathrm{~mm}$ quartz cuvettes (Hellma, Germany). Far UV spectra were measured from 260 to $190 \mathrm{~nm}$ and analyzed using the CDSSTR method to predict the secondary structure. ${ }^{45}$

NMR Spectroscopy. NMR samples were prepared by dissolving the lyophilized peptides at about $1 \mathrm{mM}$ concentration in aqueous solution $\left(\mathrm{H}_{2} \mathrm{O} / \mathrm{D}_{2} \mathrm{O} 9: 1 \mathrm{v} / \mathrm{v}\right.$ or pure $\left.\mathrm{D}_{2} \mathrm{O}\right)$ or in DPC micelles (50 $\mathrm{mM}\left[\mathrm{D}_{38}\right]$-DPC in $\mathrm{H}_{2} \mathrm{O} / \mathrm{D}_{2} \mathrm{O} 9: 1, \mathrm{v} / \mathrm{v}$ or in pure $\left.\mathrm{D}_{2} \mathrm{O}\right)$. The $\mathrm{pH}$ was measured using a glass microelectrode and adjusted to 4.4 by addition of $\mathrm{NaOD}$ or $\mathrm{DCl}$. Sodium 2,2-dimethyl-2-silapentane-5-sulfonate (DSS) at a $0.1-0.2 \mathrm{mM}$ concentration was added as internal reference for the ${ }^{1} \mathrm{H}$ chemical shifts.

As previously reported, ${ }^{46}$ a Bruker Avance-600 spectrometer equipped with a cryoprobe was used to record NMR spectra: 1D ${ }^{1} \mathrm{H}, \quad 2 \mathrm{D} \quad{ }^{1} \mathrm{H},{ }^{1} \mathrm{H}$-COSY (phase-sensitive two-dimensional correlated spectroscopy), ${ }^{1} \mathrm{H},{ }^{1} \mathrm{H}$-TOCSY (total correlated spectroscopy), ${ }^{1} \mathrm{H},{ }^{1} \mathrm{H}$ NOESY (nuclear Overhauser enhancement spectroscopy), and ${ }^{1} \mathrm{H}-{ }^{13} \mathrm{C}$-HSQC (heteronuclear single quantum coherence) at ${ }^{13} \mathrm{C}$ natural abundance. TOCSY and NOESY mixing times were 60 and $150 \mathrm{~ms}$, respectively. Data were processed using the TOPSPIN software (Bruker Biospin, Karlsruhe, Germany).

SPARKY software ${ }^{47}$ was used to analyze the NMR spectra. The ${ }^{1} \mathrm{H}$ chemical shifts were assigned by analysis of the $2 \mathrm{D}$ homonuclear spectra using the well-established sequential assignment methodology, ${ }^{48}$ and the ${ }^{1} \mathrm{H}^{13} \mathrm{C}-\mathrm{HSQC}$ spectra were analyzed to assign the ${ }^{13} \mathrm{C}$ chemical shifts. The assigned chemical shifts have been deposited at the BioMagResBank (http://www.bmrb.wisc.edu) with accession codes BMRB ID: 50486-50493.

The conformational shifts for $\mathrm{H} \alpha$ protons $\left(\Delta \delta_{\mathrm{H} \alpha}, \mathrm{ppm}\right)$ and $\mathrm{C} \alpha$ carbons $\left(\Delta \delta_{\mathrm{C} \alpha}, \mathrm{ppm}\right)$ were obtained using the following equations: $\Delta \delta_{\mathrm{H} \alpha}=\delta_{\mathrm{H} \alpha}{ }^{\text {observed }}-\delta_{\mathrm{H} \alpha}^{\mathrm{RC}}, \mathrm{ppm}$ and $\Delta \delta \mathrm{C} \alpha=\delta_{\mathrm{C} \alpha}{ }^{\text {observed }}-\delta_{\mathrm{C} \alpha}{ }^{\mathrm{RC}}$, ppm; where $\delta_{\mathrm{H} \alpha}^{\text {observed }}$ and $\delta \mathrm{C} \alpha^{\text {observed }}$ are, respectively, the $\mathrm{H} \alpha$ and 
$\mathrm{C} \alpha$ chemical shifts observed for the peptides, and the random coil values $\delta_{\mathrm{H} \alpha}^{\mathrm{RC}}$ and $\delta_{\mathrm{C} \alpha}{ }^{\mathrm{RC}}$ were taken from ref 49 .

Helix populations were estimated from the ${ }^{1} \mathrm{H}_{\alpha}$ and ${ }^{13} \mathrm{C}_{\alpha}$ chemical shifts as previously described. ${ }^{46}$

Peptide structures were calculated using the iterative procedure for automatic NOE assignment integrated in the CYANA 3.98 program. ${ }^{50}$ This algorithm consists of seven cycles of combined automated NOE assignment and structure calculation, in which 100 conformers were computed per cycle. The experimental input data comprises the lists of assigned chemical shifts, and NOE integrated cross-peaks present in $150 \mathrm{~ms}$ NOESY spectra, plus the $\phi$ and $\psi$ dihedral angle restraints. The NOE cross-peaks were integrated using the automatic integration subroutine of the SPARKY software. ${ }^{47}$ The TALOSn webserver ${ }^{51}$ was used to obtain the dihedral angle restraints from the ${ }^{1} \mathrm{H}$ and ${ }^{13} \mathrm{C}$ chemical shifts. The final structure of each peptide is the ensemble of the 20 lowest target function conformers calculated in the last cycle. These ensembles were visualized and examined using the MOLMOL program. ${ }^{52}$ The coordinates for the calculated structures are available upon request from the authors.

\section{ASSOCIATED CONTENT}

\section{s) Supporting Information}

The Supporting Information is available free of charge at https://pubs.acs.org/doi/10.1021/acs.jmedchem.1c00795.

Peak integration data for all peptides after incubation with human serum; degradation profiles for peptides 3 and 4; A. baumannii survival ratio after incubation with peptides; antimicrobial resistance; membrane depolarization after incubation with peptides; circular dichroism spectra for peptides in the presence and absence of SDS micelles; $\Delta \delta_{\mathrm{C} \alpha}$ values for peptides 1, 2, 6, and 7 in aqueous solution and DPC micelles; NMR solution structures for peptides 1, 2, 6, and 7; NMR solution structures for C-Terminal regions of peptides 1, 2, 6, and 7; MBC values; antimicrobial activity in the presence of human serum for peptides 1, 2, 3, and 4; predicted secondary structure of peptides; averaged $\Delta \delta_{\mathrm{H} \alpha}$ and $\Delta \delta_{\mathrm{C} \alpha}$ values for peptides $1,2,6$, and 7 in aqueous solution and DPC micelles; structural statistics parameters for peptide structures 1, 2, 6, and 7; HPLC traces and MS spectra for all peptides (PDF)

Molecular formula strings (CSV)

\section{AUTHOR INFORMATION}

\section{Corresponding Authors}

Ester Boix - Department of Biochemistry and Molecular Biology, Universitat Autonoma de Barcelona, Cerdanyola del Valles 08193, Spain; 이이.org/0000-0003-1790-2142; Email: ester.boix@uab.cat

David Andreu - Department of Experimental and Health Sciences, Universitat Pompeu Fabra, Barcelona Biomedical Research Park, Barcelona 08003, Spain; 이이이.org/00000002-6317-6666; Email: david.andreu@upf.edu

Marc Torrent - Department of Biochemistry and Molecular Biology, Universitat Autonoma de Barcelona, Cerdanyola del Valles 08193, Spain; 이이이.org/0000-0001-6567-3474; Email: marc.torrent@uab.cat

\section{Authors}

Daniel Sandín - Department of Biochemistry and Molecular Biology, Universitat Autonoma de Barcelona, Cerdanyola del Valles 08193, Spain
Javier Valle - Department of Experimental and Health Sciences, Universitat Pompeu Fabra, Barcelona Biomedical Research Park, Barcelona 08003, Spain

Belén Chaves-Arquero - Departamento de Química-Física Biológica, Instituto de Química Física Rocasolano (IQFRCSIC), Madrid 28006, Spain

Guillem Prats-Ejarque - Department of Biochemistry and Molecular Biology, Universitat Autònoma de Barcelona, Cerdanyola del Valles 08193, Spain

María Nieves Larrosa - Servei de Microbiologia, Hospital Universitari Vall d'Hebron, Barcelona 08035, Spain; Departament de Genètica i Microbiologia, Universitat Autonoma de Barcelona, Cerdanyola del Valles 08193, Spain

Juan José González-López - Servei de Microbiologia, Hospital Universitari Vall d'Hebron, Barcelona 08035, Spain; Departament de Genètica i Microbiologia, Universitat Autonoma de Barcelona, Cerdanyola del Valles 08193, Spain

María Ángeles Jiménez - Departamento de Química-Física Biológica, Instituto de Química Física Rocasolano (IQFRCSIC), Madrid 28006, Spain; (1) orcid.org/0000-00016835-5850

Complete contact information is available at: https://pubs.acs.org/10.1021/acs.jmedchem.1c00795

\section{Author Contributions}

E.B., D.A., and M.T. designed, directed, obtained funding, and coordinated the study. D.S. performed the synthesis of the peptides, supervised by J.V.; the antimicrobial assays, assisted by G.P.E., M.N.L., and J.J.G., and the remaining experimental work other than the NMR experiments, carried out by B.C.-A., supervised by M.A.J., who analyzed the results and contributed the corresponding text, tables, and figures. D.S. wrote an initial version of the paper, subsequently edited by D.A. and M.T. All authors contributed to editing and revising the final version of the manuscript.

\section{Funding}

This work was supported by the Spanish Ministerio de Ciencia, Innovación y Universidades: SAF2015-72518-EXP, SAF201782158-R and RYC-2012-09999 to M.T.; CTQ2017-84371-P to M.A.J.; AGL2014-52395-C2; AGL2017-84097-C2-2-R to D.A. and PID2019-106123GB-I00 to E.B. Additional financial support from the European Society for Clinical Microbiology and Infectious Disease, ESCMID 2016, to M.T., the Secretaria d'Universitats i Recerca del Departament d'Empresa i Coneixement de la Generalitat de Catalunya, 2019 LLAV 00029 to M.T. and 2016 PROD 00060 to E.B. The "Maria de Maeztu" Program for Units of Excellence in R\&D from the Spanish Ministry of Innovation and Competitiveness (MINECO) for work at Pompeu Fabra University (D.A.) is acknowledged. This work was supported, in part, by the European Regional Development Fund 'A Way to Achieve Europe' [Spanish Network for Research in Infectious Diseases (Grant No. RD16/0016/0003)]. D.S. and B.C.-A. are recipients of pre-doctoral FPI scholarships (PRE2018-083243 and BES-2015-073383, respectively) from the Spanish Ministerio de Ciencia, Innovación y Universidades.

\section{Notes}

The authors declare no competing financial interest.

\section{ACKNOWLEDGMENTS}

The NMR experiments were performed in the "Manuel Rico" NMR laboratory, LMR, CSIC, a node of the Spanish Large- 
Scale National Facility ICTS R-LRB. CD and Fluorescence measurements were performed at the Laboratory of Luminescence and Biomolecule Spectroscopy (LLEB) and SEM was performed at the Servei de Microscopia (SM) under the supervision of Dr. Alex Sánchez, at the Universidad Autònoma de Barcelona.

\section{ABBREVIATIONS}

AMP, antimicrobial peptide; ECP, eosinophil cationic protein; $\mathrm{ACN}$, acetonitrile; MIC, minimum inhibitory concentration; Orn, ornithine; Dab, 2,4-diaminobutyric acid; Har, homoarginine; PBS, phosphate buffered saline; MTT, 3-(4,5dimethylthiazol-2-yl)-2,5-diphenyltetrazolium bromide

\section{REFERENCES}

(1) Laxminarayan, R.; Duse, A.; Wattal, C.; Zaidi, A. K. M.; Wertheim, H. F. L.; Sumpradit, N.; Vlieghe, E.; Hara, G. L.; Gould, I. M.; Goossens, H.; Greko, C.; So, A. D.; Bigdeli, M.; Tomson, G.; Woodhouse, W.; Ombaka, E.; Peralta, A. Q.; Qamar, F. N.; Mir, F.; Kariuki, S.; Bhutta, Z. A.; Coates, A.; Bergstrom, R.; Wright, G. D.; Brown, E. D.; Cars, O. Antibiotic Resistance - the Need for Global Solutions. Lancet Infect. Dis. 2013, 13, 1057-1098.

(2) Nolte, O. Antimicrobial Resistance in the 21st Century: A Multifaceted Challenge. Protein Pept. Lett. 2014, 330-335.

(3) Gelband, H.; Laxminarayan, R. Tackling Antimicrobial Resistance at Global and Local Scales. Trends Microbiol. 2015, 23, 524-526.

(4) Neu, H. C. The Crisis in Antibiotic Resistance. Science 1992, 257, 1064-1073.

(5) Sierra, J. M.; Fusté, E.; Rabanal, F.; Vinuesa, T.; Viñas, M. An Overview of Antimicrobial Peptides and the Latest Advances in Their Development. Expert Opin. Biol. Ther. 2017, 17, 663-676.

(6) Ghosh, C.; Sarkar, P.; Issa, R.; Haldar, J. Alternatives to Conventional Antibiotics in the Era of Antimicrobial Resistance. Trends Microbiol. 2019, 27, 323-338.

(7) Ganz, T.; Lehrer, R. I. Antimicrobial Peptides of Vertebrates. Curr. Opin. Immunol. 1998, 10, 41-44.

(8) Hassan, M.; Kjos, M.; Nes, I. F.; Diep, D. B.; Lotfipour, F. Natural Antimicrobial Peptides from Bacteria: Characteristics and Potential Applications to Fight against Antibiotic Resistance. J. Appl. Microbiol. 2012, 113, 723-736.

(9) Nawrot, R.; Barylski, J.; Nowicki, G.; Broniarczyk, J.; Buchwald, W.; Goździcka-Józefiak, A. Plant Antimicrobial Peptides. Folia Microbiol. 2014, 59, 181-196.

(10) Wiesner, J.; Vilcinskas, A. Antimicrobial Peptides: The Ancient Arm of the Human Immune System. Virulence 2010, 1, 440-464.

(11) Brogden, K. A. Antimicrobial Peptides: Pore Formers or Metabolic Inhibitors in Bacteria? Nat. Rev. Microbiol. 2005, 3, 238250.

(12) Boix, E.; Nogués, M. V. Mammalian Antimicrobial Proteins and Peptides: Overview on the RNase A Superfamily Members Involved in Innate Host Defence. Mol. BioSyst. 2007, 3, 317-335.

(13) Koczera, P.; Martin, L.; Marx, G.; Schuerholz, T. The Ribonuclease A Superfamily in Humans: Canonical RNases as the Buttress of Innate Immunity. Int. J. Mol. Sci. 2016, 17, 1278.

(14) Lu, L.; Li, J.; Moussaoui, M.; Boix, E. Immune modulation by human secreted RNases at the extracellular space. Front. Immunol. 2018, 8 (1499), 1-17.

(15) Lehrer, R. I.; Szklarek, D.; Barton, A.; Ganz, T.; Hamann, K. J.; Gleich, G. J. Antibacterial Properties of Eosinophil Major Basic Protein and Eosinophil Cationic Protein. J. Immunol. 1989, 142, $4428-4434$.

(16) Yang, D.; Rosenberg, H. F.; Chen, Q.; Dyer, K. D.; Kurosaka, K.; Oppenheim, J. J. Eosinophil-Derived Neurotoxin (EDN), an Antimicrobial Protein with Chemotactic Activities for Dendritic Cells. Blood 2003, 102, 3396-3403.
(17) Maeda, T.; Kitazoe, M.; Tada, H.; de Llorens, R.; Salomon, D. S.; Ueda, M.; Yamada, H.; Seno, M. Growth Inhibition of Mammalian Cells by Eosinophil Cationic Protein. Eur. J. Biochem. 2002, 269, 307-316.

(18) Malik, A.; Batra, J. K. Antimicrobial Activity of Human Eosinophil Granule Proteins: Involvement in Host Defence against Pathogens. Crit. Rev. Microbiol. 2012, 38, 168-181.

(19) Torrent, M.; Pulido, D.; Valle, J.; Nogués, M. V.; Andreu, D.; Boix, E. Ribonucleases as a Host-Defence Family: Evidence of Evolutionarily Conserved Antimicrobial Activity at the N-Terminus. Biochem. J. 2013, 456, 99-108.

(20) Bystrom, J.; Amin, K.; Bishop-Bailey, D. Analysing the Eosinophil Cationic Protein - a Clue to the Function of the Eosinophil Granulocyte. Respir. Res. 2011, 12, 10.

(21) Boix, E.; Salazar, V. A.; Torrent, M.; Pulido, D.; Nogués, M. V.; Moussaoui, M. Structural Determinants of the Eosinophil Cationic Protein Antimicrobial Activity. Biol. Chem. 2012, 393, 801-815.

(22) Torrent, M.; de la Torre, B. G.; Nogués, V. M.; Andreu, D.; Boix, E. Bactericidal and Membrane Disruption Activities of the Eosinophil Cationic Protein Are Largely Retained in an N-Terminal Fragment. Biochem. J. 2009, 421, 425-434.

(23) Torrent, M.; Odorizzi, F.; Nogués, M. V.; Boix, E. Eosinophil Cationic Protein Aggregation: Identification of an N-Terminus Amyloid Prone Region. Biomacromolecules 2010, 11, 1983-1990.

(24) Torrent, M.; Pulido, D.; de la Torre, B. G.; García-Mayoral, M. F.; Nogués, M. V.; Bruix, M.; Andreu, D.; Boix, E. Refining the Eosinophil Cationic Protein Antibacterial Pharmacophore by Rational Structure Minimization. J. Med. Chem. 2011, 54, 5237-5244.

(25) Vlieghe, P.; Lisowski, V.; Martinez, J.; Khrestchatisky, M. Synthetic Therapeutic Peptides: Science and Market. Drug Discovery Today 2010, 15, 40-56.

(26) López-Otín, C.; Matrisian, L. M. Emerging Roles of Proteases in Tumour Suppression. Nat. Rev. Cancer 2007, 7, 800-808.

(27) Carmona, G.; Rodriguez, A.; Juarez, D.; Corzo, G.; Villegas, E. Improved Protease Stability of the Antimicrobial Peptide Pin2 Substituted with D-Amino Acids. Protein J. 2013, 32, 456-466.

(28) Ravikumar, Y.; Nadarajan, S. P.; Hyeon Yoo, T.; Lee, C.-s.; Yun, H. Unnatural Amino Acid Mutagenesis-Based Enzyme Engineering. Trends Biotechnol. 2015, 33, 462-470.

(29) Pulido, D.; Prats-Ejarque, G.; Villalba, C.; Albacar, M.; González-López, J. J.; Torrent, M.; Moussaoui, M.; Boix, E. A Novel RNase 3/ECP Peptide for Pseudomonas Aeruginosa Biofilm Eradication That Combines Antimicrobial, Lipopolysaccharide Binding, and Cell-Agglutinating Activities. Antimicrob. Agents Chemother. 2016, 60, 6313-6325.

(30) Hedstrom, L. Serine Protease Mechanism and Specificity. Chem. Rev. 2002, 102, 4501-4524.

(31) Gentilucci, L.; De Marco, R.; Cerisoli, L. Chemical Modifications Designed to Improve Peptide Stability: Incorporation of Non-Natural Amino Acids, Pseudo-Peptide Bonds, and Cyclization. Curr. Pharm. Des. 2010, 16, 3185-3203.

(32) Zou, G.; de Leeuw, E.; Li, C.; Pazgier, M.; Li, C.; Zeng, P.; Lu, W.-Y.; Lubkowski, J.; Lu, W. Toward Understanding the Cationicity of Defensins: Arg and Lys Versus Their Noncoded Analogs. J. Biol. Chem. 2007, 282, 19653-19665.

(33) Nan, Y. H.; Park, I.-S.; Hahm, K.-S.; Shin, S. Y. Antimicrobial Activity, Bactericidal Mechanism and LPS-Neutralizing Activity of the Cell-Penetrating Peptide PVEC and Its Analogs. J. Pept. Sci. 2011, 17, 812-817.

(34) Luong, H. X.; Kim, D.-H.; Lee, B.-J.; Kim, Y.-W. Effects of Lysine-to-Arginine Substitution on Antimicrobial Activity of Cationic Stapled Heptapeptides. Arch. Pharmacal Res. 2018, 41, 1092-1097.

(35) Liu, H.; Lei, M.; Du, X.; Cui, P.; Zhang, S. Identification of a Novel Antimicrobial Peptide from Amphioxus Branchiostoma Japonicum by in Silico and Functional Analyses. Sci. Rep. 2015, 5, 18355.

(36) Drin, G.; Antonny, B. Amphipathic Helices and Membrane Curvature. FEBS Lett. 2010, 584, 1840-1847. 
(37) Zhang, L.; Kang, H.; Vázquez, F. X.; Toledo-Sherman, L.; Luan, B.; Zhou, R. Molecular Mechanism of Stabilizing the Helical Structure of Huntingtin N17 in a Micellar Environment. J. Phys. Chem. B 2017, 121, 4713-4721.

(38) Hicks, R. P.; Abercrombie, J. J.; Wong, R. K.; Leung, K. P. Antimicrobial Peptides Containing Unnatural Amino Acid Exhibit Potent Bactericidal Activity against ESKAPE Pathogens. Bioorg. Med. Chem. 2013, 21, 205-214.

(39) Hong, S. Y.; Oh, J. E.; Lee, K.-H. Effect of D-Amino Acid Substitution on the Stability, the Secondary Structure, and the Activity of Membrane-Active Peptide. Biochem. Pharmacol. 1999, 58, $1775-1780$.

(40) Guina, T.; Yi, E. C.; Wang, H.; Hackett, M.; Miller, S. I. A PhoP-Regulated Outer Membrane Protease of Salmonella Enterica Serovar Typhimurium Promotes Resistance to Alpha-Helical Antimicrobial Peptides. J. Bacteriol. 2000, 182, 4077-4086.

(41) Porto, W. F.; Irazazabal, L.; Alves, E. S. F.; Ribeiro, S. M.; Matos, C. O.; Pires, Á. S.; Fensterseifer, I. C. M.; Miranda, V. J.; Haney, E. F.; Humblot, V.; Torres, M. D. T.; Hancock, R. E. W.; Liao, L. M.; Ladram, A.; Lu, T. K.; de la Fuente-Nunez, C.; Franco, O. L. In Silico Optimization of a Guava Antimicrobial Peptide Enables Combinatorial Exploration for Peptide Design. Nat. Commun. 2018, 9, 1490 .

(42) Wiegand, I.; Hilpert, K.; Hancock, R. E. W. Agar and Broth Dilution Methods to Determine the Minimal Inhibitory Concentration (MIC) of Antimicrobial Substances. Nat. Protoc. 2008, 3, $163-175$.

(43) Zhang, L.; Dhillon, P.; Yan, H.; Farmer, S.; Hancock, R. E. W. Interactions of Bacterial Cationic Peptide Antibiotics with Outer and Cytoplasmic Membranes of Pseudomonas Aeruginosa. Antimicrob. Agents Chemother. 2000, 44, 3317-3321.

(44) Torrent, M.; Badia, M.; Moussaoui, M.; Sanchez, D.; Nogués, M. V.; Boix, E. Comparison of Human RNase 3 and RNase 7 Bactericidal Action at the Gram-Negative and Gram-Positive Bacterial Cell Wall. FEBS J. 2010, 277, 1713-1725.

(45) Sreerama, N.; Woody, R. W. Estimation of Protein Secondary Structure from Circular Dichroism Spectra: Comparison of CONTIN, SELCON, and CDSSTR Methods with an Expanded Reference Set. Anal. Biochem. 2000, 287, 252-260.

(46) Chaves-Arquero, B.; Pérez-Cañadillas, J. M.; Jiménez, M. A. Effect of Phosphorylation on the Structural Behaviour of Peptides Derived from the Intrinsically Disordered C-Terminal Domain of Histone H1.0. Chem. Eur. J. 2020, 26, 5970-5981.

(47) Goddard, T. D.; Kneller, D. G. SPARKY 3; University of California. San Francisco, CA. 2008.

(48) Wüthrich, K. NMR with Proteins and Nucleic Acids. Eur. News 1986, 17, 11-13.

(49) Wishart, D. S.; Bigam, C. G.; Yao, J.; Abildgaard, F.; Dyson, H. J.; Oldfield, E.; Markley, J. L.; Sykes, B. D. ${ }^{1} \mathrm{H},{ }^{13} \mathrm{C}$ and ${ }^{15} \mathrm{~N}$ Chemical Shift Referencing in Biomolecular NMR. J. Biomol. NMR 1995, 6, 135-140.

(50) Güntert, P. Automated NMR Structure Calculation with CYANA. Methods Mol. Biol. 2004, 278, 353-378.

(51) Shen, Y.; Bax, A. Protein Backbone and Sidechain Torsion Angles Predicted from NMR Chemical Shifts Using Artificial Neural Networks. J. Biomol. NMR 2013, 56, 227-241.

(52) Koradi, R.; Billeter, M.; Wüthrich, K. MOLMOL: A Program for Display and Analysis of Macromolecular Structures. J. Mol. Graph. 1996, 14, 51-55.

\section{NOTE ADDED AFTER ASAP PUBLICATION}

The version of this paper that was published ASAP August 3, 2021, contained an error in footnote $b$ of Table 1. The corrected version was reposted August 12, 2021. 